\title{
Splicing modulator FR901464 is a potential agent for colorectal cancer in combination therapy
}

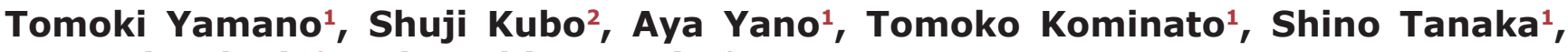 \\ Masataka Ikeda ${ }^{1}$ and Naohiro Tomita ${ }^{1}$ \\ ${ }^{1}$ Division of Lower Gastrointestinal Surgery, Hyogo College of Medicine, Nishinomiya, Hyogo, Japan \\ ${ }^{2}$ Laboratory of Molecular and Genetic Therapeutics, Institute for Advanced Medical Sciences, Hyogo College of Medicine, \\ Nishinomiya, Hyogo, Japan
}

Correspondence to: Tomoki Yamano, email: yamanot@hyo-med.ac.jp

Keywords: SF3B1; splicing; modulator; colorectal cancer; combination

Received: April 12, $2018 \quad$ Accepted: December 29, $2018 \quad$ Published: January 08, 2019

Copyright: Yamano et al. This is an open-access article distributed under the terms of the Creative Commons Attribution License 3.0 (CC BY 3.0), which permits unrestricted use, distribution, and reproduction in any medium, provided the original author and source are credited.

\section{ABSTRACT}

FR901464 (FR) was first described as an anticancer drug and later identified as a modulator of splicing factor $3 B$ subunit 1 (SF3B1). Although the effectiveness of splicing modulators has been investigated in colorectal cancer (CRC) cells, their usefulness in animal experiments has not been confirmed. The association of SF3B1 with CRC progression and the influence of FR on transcriptional activity in CRC has not been fully elucidated. FR showed strong cytotoxicity against CRC cell lines, SF3B1mutated cancer cell lines, and human fibroblasts with IC $_{50}$ values less than $1 \mathrm{ng} / \mathrm{ml}$. FR-resistant clones derived from HCT116, DLD1, Lovo, and CT26 cells showed IC 50 values greater than $100 \mathrm{ng} / \mathrm{ml}$. SF3B1 sequencing demonstrated low frequencies of SF3B1 mutations in CRC and mutations in codon 1074 of exon 22 in all FR-resistant clones. Unlike hematological malignancies, SF3B1 expression was not associated with CRC progression. Although FR showed significant growth inhibition in a xenograft model of RKO cells, severe toxicity was also induced. These data indicated CRC might be a suitable target of FR unless toxicity occurs. Microarray analysis and real-time quantitative PCR demonstrated downregulation of genes associated with Fanconi anemia (BRCA1 and BRCA2) and 28 driver oncogenes. These data suggested combination treatment of FR with other anticancer drugs whose sensitivity is associated with genes affected by FR treatment. Combination treatment with PARP1 inhibitor olaparib, whose sensitivity was enhanced by BRCA 1/2 deficiency, showed synergistic effects in CRC cells. Our data indicates the potential of FR in combination therapy rather than monotherapy for CRC treatment.

\section{INTRODUCTION}

FR901464 (FR) and FR901228 were discovered as anticancer drugs by Nakajima et al. [1-3] and were subsequently identified as a SF3B1 inhibitor and a histone deacetylase inhibitor (HDACI), respectively [4, 5]. FR901228 and other HDACIs with different chemical structures have similar biological effects on cancer cells, including induction of cell cycle arrest, differentiation, and apoptosis, by influencing transcriptional activity $[6,7]$. Because FR was also shown to enhance the transcriptional activity of SV40 promoter [1] we postulated that FR might also have biological effects in cancer cells by influencing transcriptional activity.

In 2007, FR, its methylated derivative Spliceostatin A (SSA), and Pladienolides were identified as inhibitors of splicing factor 3B subunit 1 (SF3B1), a critical spliceosome component that plays a role in the synthesis of mature mRNA by editing pre-mRNA molecules [5, 8]. Since then, Pladienolides and FR analogues including SSA and Meayamaicin have been investigated as anticancer drugs by modulating splicing through targeting the SF3B1 subunit of the spliceosome [9-24]. 
In 2011, SF3B1 mutations were identified in hematological malignancies including myelodysplastic syndromes (MDS) and chronic lymphocytic leukemia (CLL) using next-generation sequencing [25-30]. In MDS, $S F 3 B 1$ mutations are present at frequencies of $20 \%-30 \%$ and are associated with the presence of ring sideroblasts and with favorable clinical outcomes and a lower incidence of leukemia [25-27]. In CLL, SF3B1 mutations are present in approximately $10 \%-15 \%$ of patients and are associated with accelerated disease progression and poor survival [28-30]. Some solid tumors, including uveal melanoma [31-33], breast cancer [34, 35], and pancreatic cancer [36], have relatively low frequencies of $S F 3 B 1$ mutations compared with hematological malignancies. In uveal melanoma, SF3B1 mutations are associated with alternative splicing and indicate a good prognosis [33]. These mutations were identified between exon 10 and exon 16, including at mutational hot spots between exons 12 and 15 [26].

Colorectal cancer (CRC) is one of the most common malignancies in Western countries and Japan [37]. Advanced metastatic CRC is still a lethal disease despite the recent application of combination chemotherapy involving 5-fluorouracil (5-FU) and oxaliplatin (OHP) or irinotecan with molecular targeted therapy against vascular endothelial growth factor (VEGF) and epidermal growth factor receptor (EGFR) [38].

Yokoi et al. and Teng et al. reported $S F 3 B 1$ mutations at codon 1074 (exon 22) in CRC cells resistant to Pladienolides [16, 23]. CRC cell lines have been widely used for the study of splicing modulators $[11,13-15,18$, 22]. However, the development of splicing modulators for CRC treatment has been limited and the influence of SF3B1 on CRC progression was not determined.

In the present study, we assessed the possible application of the splicing modulator FR for CRC treatment. First, we evaluated the cytotoxic effect of FR on $\mathrm{CRC}$ in vitro and in vivo. Next, we analyzed $S F 3 B 1$ mutations and expression in CRC cell lines and CRC tumors to assess the association between $S F 3 B 1$ and CRC progression. Then, the influence of FR on transcriptional activity and alternative splicing was evaluated. Finally, based on the influence of FR on BRCA1 and BRCA2, we evaluated combination treatment with FR and the PARP1 inhibitor olaparib in CRC cells to explore the possible application of FR with other anticancer drugs.

\section{RESULTS}

\section{Sensitivity of cancer cell lines to FR901464}

The $\mathrm{IC}_{50}$ values for $\mathrm{FR}$ in cancer cell lines and human fibroblasts were less than $1 \mathrm{ng} / \mathrm{ml}(0.18$ to 0.71 $\mathrm{ng} / \mathrm{ml}$ ) (Figure 1A). The $\mathrm{IC}_{50}$ of DLD1 $(0.71 \mathrm{ng} / \mathrm{ml})$ was highest among the cell lines tested and was significantly higher than that of all other cell lines except for HCC38.
The $\mathrm{IC}_{50}$ for HCT116 $(0.31 \mathrm{ng} / \mathrm{ml})$ was similar to that of other cells except for DLD1 and HCC 38. The $\mathrm{IC}_{50}$ for human fibroblasts $(0.18 \mathrm{ng} / \mathrm{ml})$ was the lowest but statistically similar to that of other cell lines except for DLD1, HCC38, and COLO829. The melanoma cell line COLO829 and the breast cancer cell line HCC38, which were reported to have $S F 3 B 1$ missense mutations in exons 12 and 15, respectively, are also sensitive to FR [26].

The cytotoxicity of FR depended on the time and dose of treatment (Figure 1B and Figure 1C). Treatment with FR for $3 \mathrm{~h}$ and $6 \mathrm{~h}$ induced similar cytotoxicity to 12 $\mathrm{h}$ of treatment in HCT116 and DLD1 cells, respectively, using Dunnett's test.

\section{Drug sensitivity of FR-resistant clones}

DLD/FR1, DLD/FR2, DLD/FR3, HCT/FR1, HCT/ FR2, LoVo/FR1, LoVo/FR2, LoVo/FR3, and LoVo/FR4 cell lines were derived from three cell lines (DLD1, HCT116, and LoVo) bearing microsatellite instability (MSI) and CT26/FR1 and CT26/FR2 cell lines were derived from CT26 cells with microsatellite stability (MSS) [39, 40]. $\mathrm{IC}_{50}$ values for FR were $173 \mathrm{ng} / \mathrm{ml}$ in $\mathrm{HCT} / \mathrm{FR} 1,200 \mathrm{ng} / \mathrm{ml}$ in HCT/FR2, $389 \mathrm{ng} / \mathrm{ml}$ in DLD/ FR3, $236 \mathrm{ng} / \mathrm{ml}$ in LoVo/FR1, and >500 ng/ml in DLD/ FR1 and DLD/FR2 cells (Figure 1D). IC $_{50}$ values of FRresistant clones were significantly higher than those of their parental cells $(P<0.0001)$. In contrast, there were no significant differences in $\mathrm{IC}_{50}$ values of OHP (Figure $1 \mathrm{E}$ ) or 5-FU (Figure 1F) between the parental cells and their FR-resistant clones. These data suggest that the mechanisms of FR resistance in these clones did not involve cross-resistance mediated by multidrug resistance genes. Human fibroblasts were sensitive to FR and OHP as well as the other cancer cell lines.

\section{Effect of FR on tumor growth}

In mouse subcutaneous xenograft models, the antitumor effect of FR was accompanied by high toxicity. Three of seven mice receiving $0.5 \mathrm{mg} / \mathrm{kg}$ FR (Figure $1 \mathrm{G}$ ) and four of nine mice receiving $0.75 \mathrm{mg} / \mathrm{kg}$ FR (Figure $1 \mathrm{H})$ died following intraperitoneal administration of FR. However, there was significant inhibition of tumor growth in a xenograft model of RKO at day $14(P=0.038)$, day $18(P=0.04)$, and day $22(P=0.0086)$ (Figure $1 \mathrm{H})$. The lack of a significant effect of FR on HCT116-derived xenografts (Figure 1G) was consistent with results of a previous study using FR901464 analogues [13].

\section{Sequencing of $S F 3 B 1$ in cancer cell lines and CRC patients}

Sanger sequencing demonstrated that all FRresistant cell lines carried missense mutations in codon 1074 of SF3B1 (Table 1). This codon has been reported 
Table 1: Details of SF3B1 mutations

\begin{tabular}{ccc}
\hline Cell / Exon(codon) & $\mathbf{1 0}(\mathbf{4 5 1}, \mathbf{4 5 9})$ & 22(1074) \\
\hline DLD1 & $(451) \mathrm{CGA}(\mathrm{R}) \rightarrow \mathrm{TGA}(\mathrm{end})$ & - \\
$\mathrm{DLD} / \mathrm{FR} 1, \mathrm{DLD} / \mathrm{FR} 2, \mathrm{DLD} / \mathrm{FR} 3$ & $(451) \mathrm{CGA}(\mathrm{R}) \rightarrow \mathrm{TGA}(\mathrm{end})$ & $\mathrm{CGT}(\mathrm{R}) \rightarrow \mathrm{TGT}(\mathrm{C})$ \\
$\mathrm{HCT} / \mathrm{FR} 1, \mathrm{HCT} / \mathrm{FR} 2$ & - & $\mathrm{CGT}(\mathrm{R}) \rightarrow \mathrm{CAT}(\mathrm{H})$ \\
LoVo/FR1 & $(459) \mathrm{CAG}(\mathrm{Q}) \rightarrow \mathrm{TAG}(\mathrm{end})$ & $\mathrm{CGT}(\mathrm{R}) \rightarrow \mathrm{CAT}(\mathrm{H})$ \\
LoVo/FR4, LoVo/FR5 & - & $\mathrm{CGT}(\mathrm{R}) \rightarrow \mathrm{TGT}(\mathrm{C})$ \\
LoVo/FR3 & - & $\mathrm{CGT}(\mathrm{R}) \rightarrow \mathrm{CAT}(\mathrm{H})$ \\
CT26/FR1 & - & $\mathrm{CGA}(\mathrm{R}) \rightarrow \mathrm{CAA}(\mathrm{G})$ \\
$\mathrm{CT} 26 /$ FR2 & - & $\mathrm{CGA}(\mathrm{R}) \rightarrow \mathrm{ATT}(\mathrm{I})$ \\
\hline
\end{tabular}

Table 2: Background of samples (number of samples with mutation/number of samples analyzed)

\begin{tabular}{lccccc}
\hline Exons analyzed & & $\mathbf{1 - 2 5}$ & $\mathbf{8 , 1 0 , 1 2 - 1 5 , 2 2}$ & $\mathbf{8 , 1 0 , 2 2}$ & Total \\
\hline CRC cell lines & & $1 / 6$ (exon 10) & - & - & $1 / 6$ \\
CRC tumors & & $0 / 75$ & $0 / 66$ & $0 / 105$ & $0 / 246$ \\
& MSS & 45 & 66 & 105 & \\
\multirow{3}{*}{ Other Tumors } & MSI & 30 & 0 & 0 & $0 / 7$ \\
& & $0 / 6$ & - & $0 / 1$ & \\
& MSS & 5 & & 0 & $1 / 259$ \\
\hline \multicolumn{1}{c}{ Total } & MSI & 1 & $0 / 66$ & $0 / 106$ & \\
\hline
\end{tabular}

Abbreviations: CRC; colorectal cancer; MSS, microsatellite stable, MSI; microsatellite instable.

to be associated with drug resistance to other splicing modulators [16, 23]. Two types of mutation were present in the human cells: CGT to TGT (Arg1074Cys) in DLD1/ FR1, DLD/FR2, DLD/FR3, and LoVo/FR2 cells; and CGT to CAT (Arg1074His) in HCT/FR1, HCT/FR2, LoVo/FR1, LoVo/FR3, and LoVo/FR4 cells (Table 1). We also detected nonsense mutations in SF3B1 exon 10 in DLD1 (Arg451Stop) and LoVo-FR1 (Gln459Stop). Murine CT26 cells contained the missense mutation CGA to CAA (Arg1074Gln) in CT26/FR1 and CGA to ATT (Arg1074Ile) due to insertion of AAA in codon 1070 in CT26/FR2.

All human FR-resistant clones were derived from human CRC cells with MSI, which are known to carry many gene mutations [38]. We sequenced all of the $S F 3 B 1$ exons in 50 patients with MSS (45 CRC and five other tumors) and in 31 patients with MSI ( 30 with CRC and one with small bowel gastrointestinal stromal tumor) but no mutations were detected in these 81 patients (Table 2).

All human FR-resistant clones and their parental cells had silent mutations in SF3B1 exon 8 (codon 320 in LoVo and codon 371 in DLD1 and HCT116), whereas the other samples had no exon 8 mutations. Therefore, we postulated that mutations in exon 8 could be used to predict the possibility of $S F 3 B 1$ exon 10 or exon 22 mutations. We further assessed samples from $171 \mathrm{CRC}$ tumors and one metastatic renal cancer in the colon and found no $S F 3 B 1$ mutation in exons 8, 10, and 22 (Table 2). Of the 171 CRC tumors, we found $66 \mathrm{CRC}$ tumors bore no $S F 3 B 1$ mutation in exons $12-15$, which were recognized as mutational hotspots in other malignancies [26].

We found no $S F 3 B 1$ mutations in these 253 tumors including 246 CRC tumors (Table 2). These data suggest that $S F 3 B 1$ mutations are rare in malignancies of the lower gastrointestinal tract irrespective of MSI or MSS status.

\section{Influence of FR, SF3B1 mutation, and CRC progression on $S F 3 B 1$ expression}

FR treatment had a limited effect on SF3B1 expression in CRC cell lines, with a 2 -fold change at most (Figure 2A). FR did not affect $S F 3 B 1$ expression in DLD1 cells. However, in HCT116 cells, $S F 3 B 1$ expression was enhanced by $1-3 \mathrm{~h}$ of FR treatment and inhibited by $24 \mathrm{~h}$ of FR treatment. SF3B1 expression in FR-resistant clones was unaffected by FR treatment, similar to their parental cells (Figure 2B). 

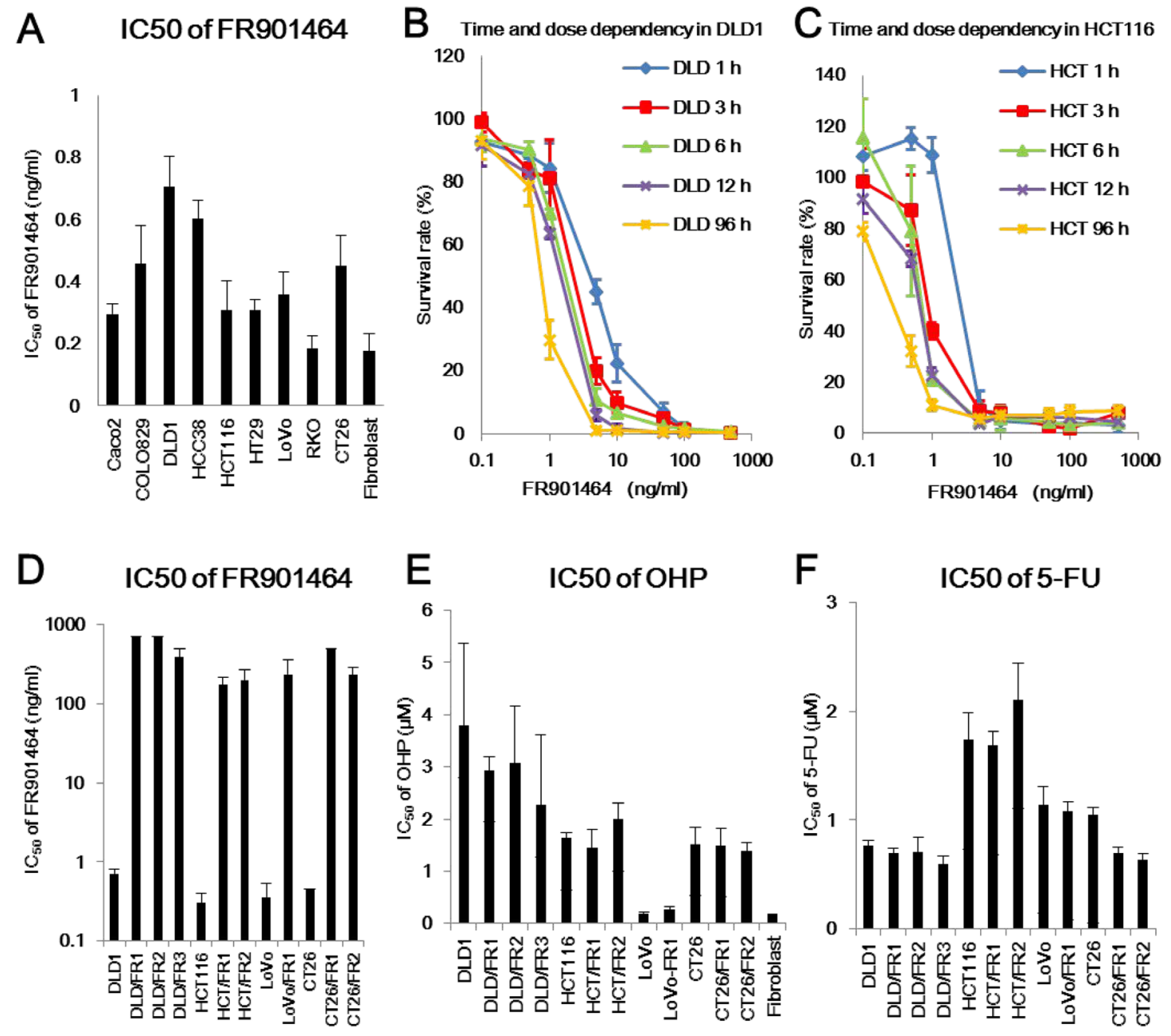

\section{G Xenograft model of HCT116}
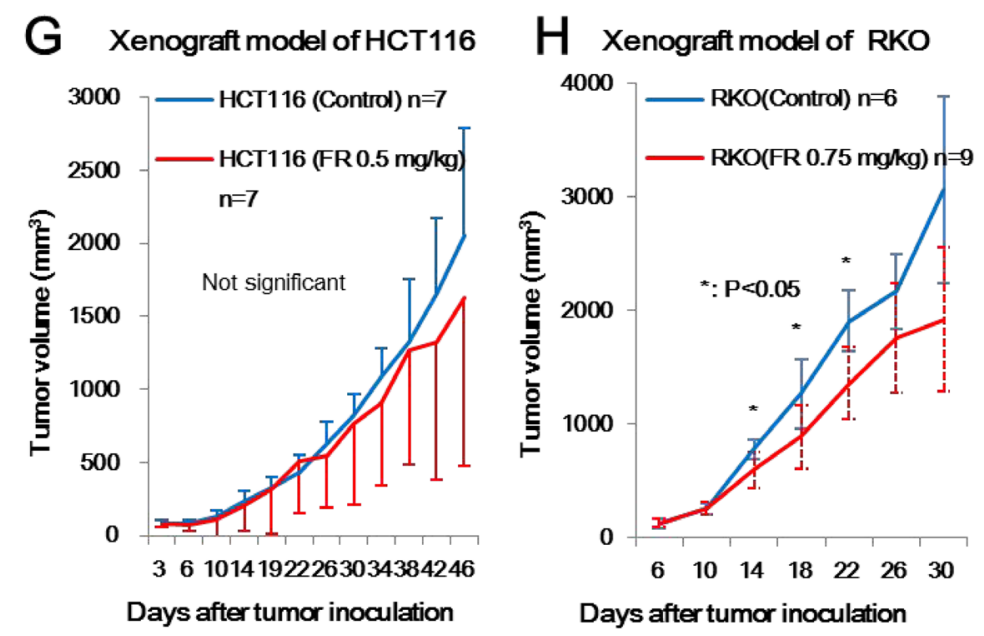

Days after tumor inoculation

Figure 1: Cytotoxic effect of FR901464 in vitro and in vivo. (A) $\mathrm{IC}_{50}$ values of $\mathrm{FR}$ in cancer cell lines. $\mathrm{The}_{\mathrm{IC}}$ values for $\mathrm{FR}$ in cancer cell lines and human fibroblasts were less than $1 \mathrm{ng} / \mathrm{ml}$ (range, 0.18 to $0.71 \mathrm{ng} / \mathrm{ml}$ ). Bars represent the mean $\mathrm{IC}_{50}$ values with standard deviations. (B, C) Time- and dose-dependency of FR cytotoxicity in DLD1 cells (B) and HCT116 cells (C). FR showed cytotoxicity after $1 \mathrm{~h}$ of treatment in both cell lines. Treatment with FR for $3 \mathrm{~h}$ and $6 \mathrm{~h}$ induced similar cytotoxicity as $12 \mathrm{~h}$ of treatment in HCT116 and DLD1 cells, respectively, using Dunnett's test. (D, E, F) IC $\mathrm{IC}_{50}$ values of FR, oxaliplatin (OHP), and 5-fluorouracil (5-FU) in parental and FR-resistant cells. FR-resistant clones showed significantly higher $\mathrm{IC}_{50}$ values of $\mathrm{FR}$ than their parental cells $(P<0.0001)$ (D). FR-resistant clones had the same $\mathrm{IC}_{50}$ values for $\mathrm{OHP}(\mathrm{E})$ and $5-\mathrm{FU}(\mathrm{F})$ as the parental cells. Bars represent mean $\mathrm{IC}_{50}$ values with standard deviations. $(\mathbf{G}, \mathbf{H})$ Cytotoxicity of FR in vivo. Tumor growth was compared between xenograft models of HCT116 (G) or RKO (H) with or without intraperitoneal injection of FR. There was a significant difference in tumor growth between mice with and without FR treatment for RKO xenografts, but not for HCT116. 
We also assessed $S F 3 B 1$ expression in cancer tissues compared with normal mucosa (relative $S F 3 B 1$ expression) in $80 \mathrm{CRC}$ patients. Relative $S F 3 B 1$ expression varied from -2.66 to 1.5 , with a median of -0.35 and mean of -0.39 (Figure 2C). There was no significant difference in relative $S F 3 B 1$ expression among patients according to clinical stage (I, 10 patients; II, 28 patients; III, 25 patients; IV, 17 patients by TNM classification version 7) [41].

These data suggested that $S F 3 B 1$ expression was not greatly influenced by FR treatment, $S F 3 B 1$ mutation, or CRC progression.

\section{Modulation of alternative splicing of $M D M 2$ and CRNDE by FR treatment or SF3B1 mutation}

We next evaluated the effect of FR treatment or $S F 3 B 1$ mutation on alternative splicing of MDM2 (Figure 2D, 2E) and CRNDE (Figure 2F, 2G), as previously described [14, 42].

As shown in Figure 2D, FR treatment (10 ng/ml and $100 \mathrm{ng} / \mathrm{ml}$ ) for $24 \mathrm{~h}$ resulted in PCR products of $1019 \mathrm{bp}$ and $785 \mathrm{bp}$ instead of a 1604-bp product as a result of modulation of alternative splicing of MDM2 in HCT116 cells but not in the FR-resistant clones HCT/FR1 and
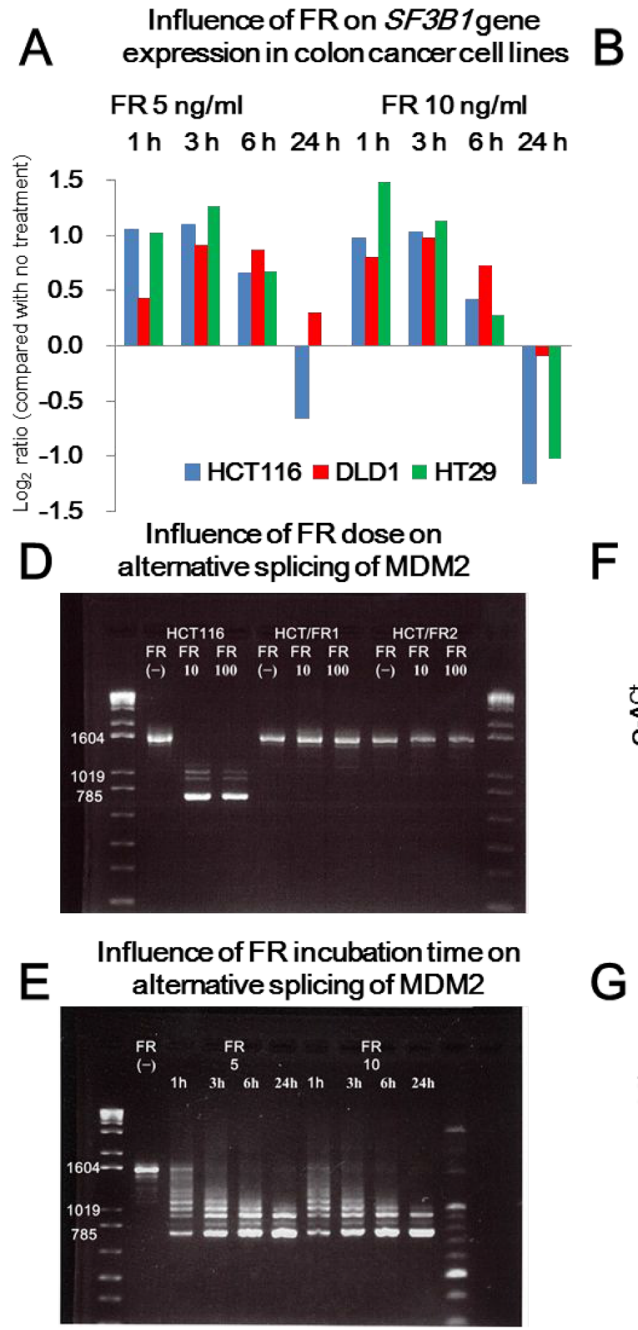

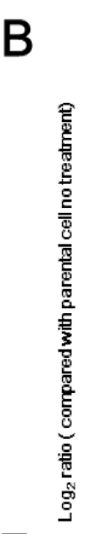

F Influence of FR on SF3B1gene expression in FR resistant clones

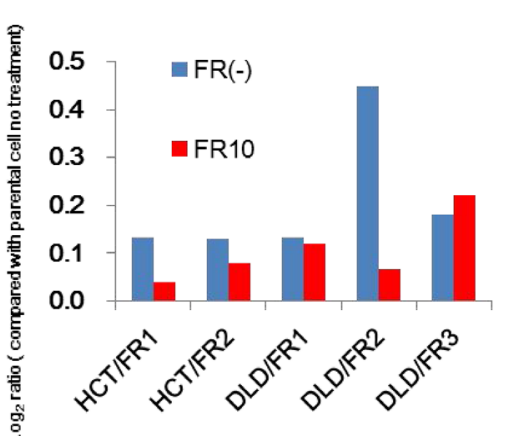

Influence of FR on alternative splicing of CRNDEin HCT116

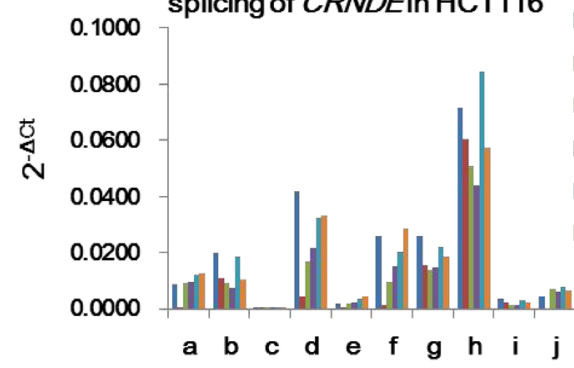

G

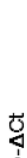

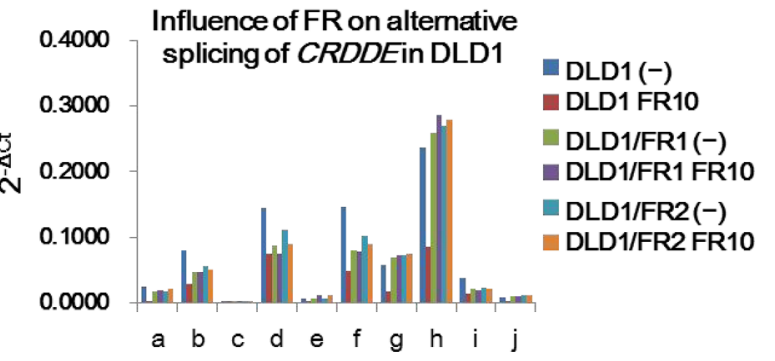
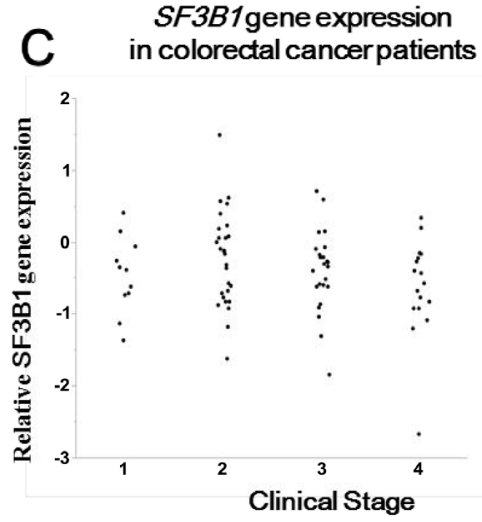

HCT116(-)

口 HCT116FR10

HCT116/FR1 (-)

- HCT116/FR1 FR10

HCT116/FR2 (-)

nCT116/FR2 FR10

Figure 2: (A, B) Influence of FR on $S F 3 B 1$ gene expression according to the duration of FR treatment (A) and presence of $S F 3 B 1$ mutation (B). A: $S F 3 B 1$ expression in HCT116 and HT29 cells was increased by FR treatment for $1-3 \mathrm{~h}$ and decreased by further treatment; however, the extent of change was two-fold at most. B: Influence of FR on SF3B1 gene expression in FR-resistant clones. SF3B1 expression of FR-resistant clones was unaffected by FR treatment. (C) $S F 3 B 1$ gene expression in CRC patients. $S F 3 B 1$ gene expression in 80 colorectal cancer tissues was compared with that in normal mucosa by real-time quantitative PCR. Relative $S F 3 B 1$ expression is shown according to TNM stage. (D, E) Influence of FR dose and incubation time on alternative splicing of MDM2. FR treatment (10 ng/ml and $100 \mathrm{ng} / \mathrm{ml})$ for $24 \mathrm{~h}$ resulted in PCR products of $1019 \mathrm{bp}$ and $785 \mathrm{bp}$ instead of a 1604-bp product due to modulation of alternative splicing of MDM2 in HCT116 cells but not in FR-resistant clones HCT/FR1 and HCT/FR2 (D). Modulation of alternative splicing was induced by $1 \mathrm{~h}$ of FR treatment, resulting in PCR products of sizes other than $1604 \mathrm{bp}(\mathrm{E}) .(\mathbf{F}, \mathbf{G})$ Influence of FR on alternative splicing of CRNDE in HCT116 and DLD1. FR treatment significantly reduced the expression of variants a, d, f, and $\mathrm{j}$ in HCT116 cells, but not in FR-resistant clones HCT/ FR1 and HCT/FR2 (F). FR treatment significantly reduced the expression of variants a, b, f, g, h, and j in DLD1 cells, but not in FR-resistant clones DLD/FR1 and DLD/FR2 (G). 
HCT/FR2 [29]. Modulation of alternative splicing was induced by $1 \mathrm{~h}$ of FR treatment, resulting in PCR products of sizes other than 1604 bp (Figure 2E).

$C R N D E$, which possesses 10 transcript variants (a, b, c, d, e, f, g, h, i, j) through alternative splicing, is highly expressed in CRC cell lines and patients [30]. FR treatment significantly reduced the expression of variants a, d, f, and $\mathrm{j}$ in HCT116, but not in FR-resistant clones HCT/FR1 and HCT/FR2 (Figure 2F). FR significantly reduced the expression of variants $a, b, f, g, h$, and $j$ in DLD1 cells, but not in FR-resistant clones DLD/FR1 and DLD/FR2 (Figure 2G). The fact that FR had a different effect on alternative splicing between HCT1116 and DLD1 cells suggests that the influence of FR on alternative splicing would vary among CRCs.

\section{Pathways affected by SF3B1 inhibition through FR treatment or SF3B1 mutation}

To evaluate the pathways affected FR inhibition of SF3B1 in CRC, we used the Agilent expression array. A total of 22,125 probes were differentially expressed on the basis of signal fold-changes of $\geq 4$ and signal differences of $\geq 100$. Hierarchical cluster analysis indicated significant differences in gene expression patterns by cell type (between DLD1 and HCT116 cells, and between HCT116 and HCT/FR1 cells) and FR treatment (between FR (-) and FR10 in both DLD1 and HCT116 cells) (Figure 3A).

$\mathrm{PC}$ analysis also showed significant differences in gene expression by cell type (between DLD1 and HCT116 cells, and between HCT116 and HCT/FR1 cells) and FR

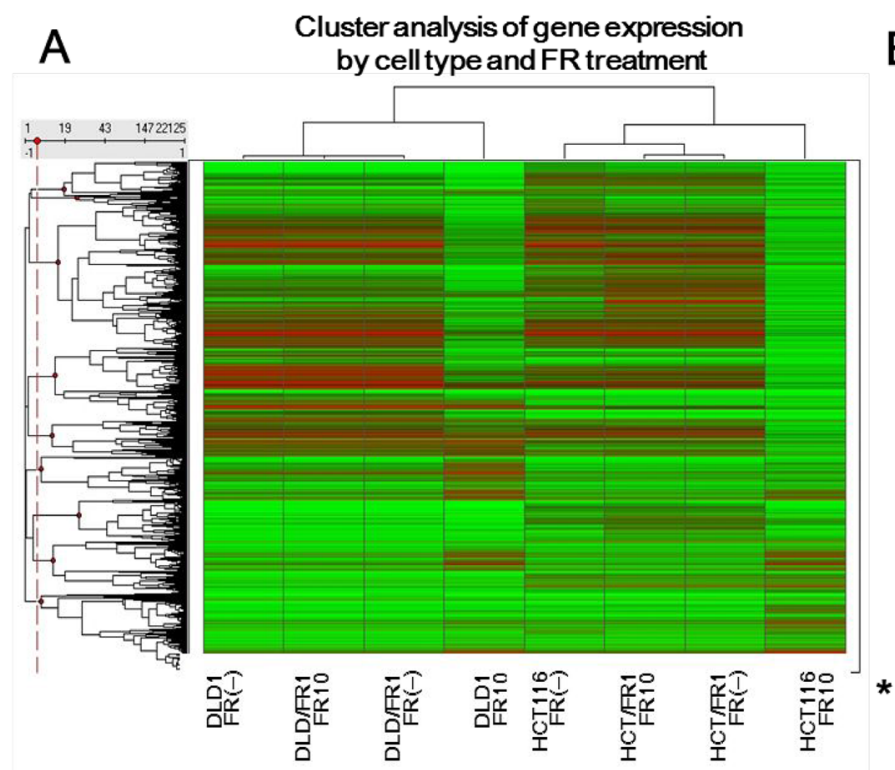

B Principal component analysis of gene expression
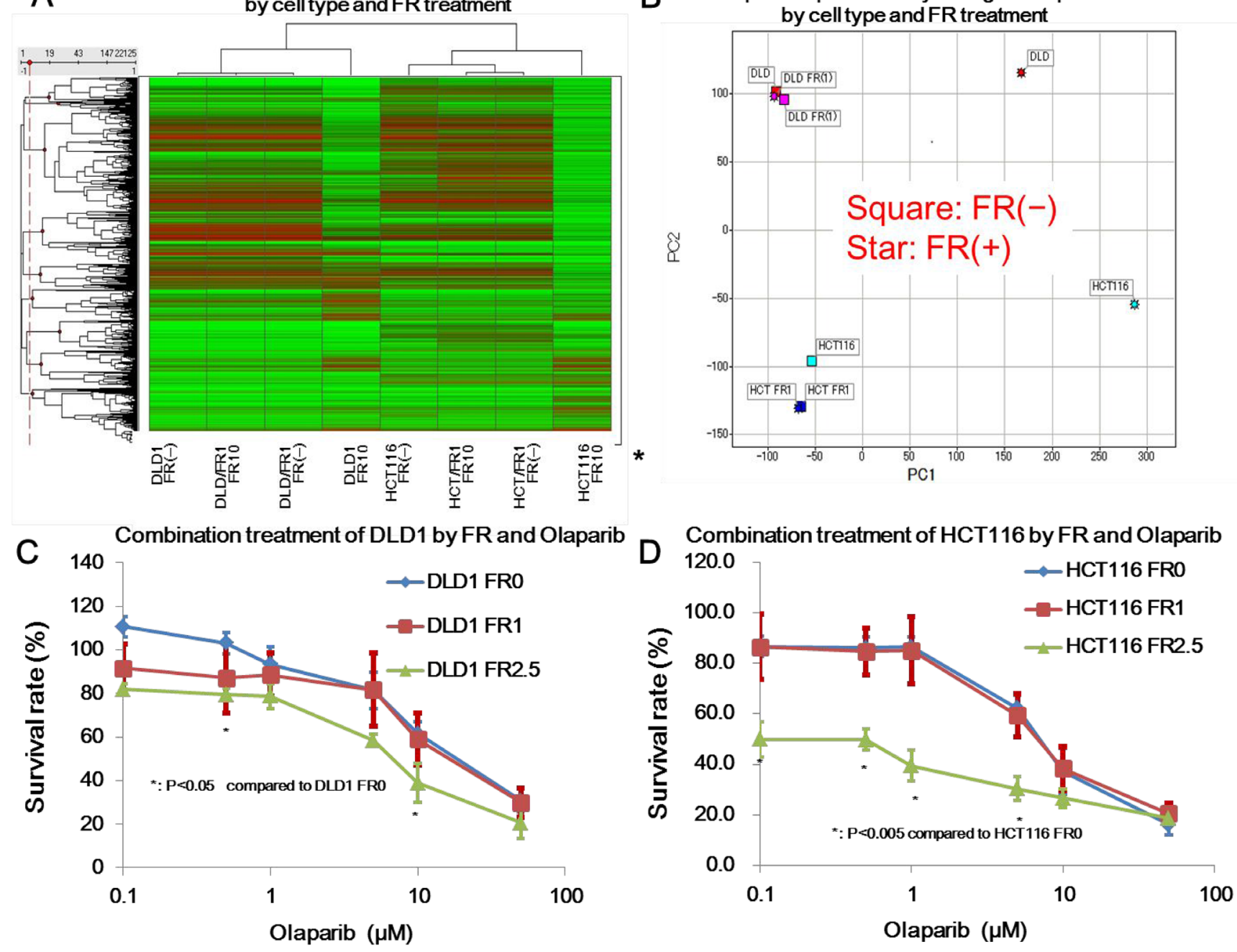

Figure 3: Microarray analysis of gene expression influenced by FR901464 and cytotoxic effect of combination treatment. (A) Cluster analysis of gene expression by cell type and FR treatment. Cluster analysis was performed based on microarray analysis data by cell type (DLD1, DLD/FR1, HCT116, or HCT/FR1) and FR treatment (no treatment, $10 \mathrm{ng} / \mathrm{ml} \mathrm{FR} \mathrm{for} 24$ h). Significant differences were observed between with and without treatment. (B) Principal component (PC) analysis of gene expression by cell type and FR treatment. Principal component analysis showed that PC1 was associated with FR treatment in both DLD1 and HCT cells, and PC2 was associated with cell type. (C, D) Combination treatment of DLD1 and HCT116 with FR and olaparib. In DLD1 cells, pretreatment with FR enhanced cytotoxicity of olaparib $(0.5 \mu \mathrm{M}$ and $10 \mu \mathrm{M})$ at an FR concentration of $2.5 \mathrm{ng} / \mathrm{ml}$ but not at $1 \mathrm{ng} / \mathrm{ml}(\mathrm{C})$. In HCT116 cells, pretreatment with FR enhanced cytotoxicity of olaparib $(0.1 \mu \mathrm{M}$ to $5 \mu \mathrm{M})$ at a concentration of $2.5 \mathrm{ng} / \mathrm{ml} \mathrm{but} \mathrm{not} \mathrm{at} 1 \mathrm{ng} / \mathrm{ml}$ (D). 
treatment (between FR (-) and FR10 in both DLD1 and HCT116 cells) (Figure 3B). In contrast, gene expression in DLD/FR1 and HCT/FR1 cells was not affected by FR treatment. PC1, but not PC2, was associated with FR treatment in both DLD1 and HCT116 cells. PC2 was associated with cell type between DLD1 and HCT116 or between HCT116 and HCT/FR1, although the difference between HCT116 and HCT/FR1 was much smaller than that between DLD1 and HCT116. The cumulative proportion of variance was $47.8 \%$ in $\mathrm{PC} 1$ and $30.3 \%$ in PC2.

We further examined the KEGG pathways according to the results of principal component analysis. A total of 2,691 probes were upregulated $\geq 2$-fold and 4,896 probes were downregulated $\geq 2$-fold in both DLD1 and HCT116 cells. Gene symbols corresponding to these probes showed that 2,474 genes were upregulated, 4,549 were downregulated, and 132 were either upregulated or downregulated depending on the probe. A total of 4,341 genes were differentially expressed in DLD/FR1 or HCT/ FR1 compared with their parental cells; of these, 149 genes were upregulated and 30 were downregulated in both DLD/FR1 and HCT/FR1. Therefore, the influence of FR treatment on changes in gene expression was much more consistent in CRC cell lines than in FR-resistant clones.

Pathway analysis predicted the enrichment of several significant pathways. The pathways that were significantly influenced in $\mathrm{PC} 1$, which represented differences in FR treatment, were different from those in PC2, which represented differences in cell type (Table 3). These results indicated that FR treatment significantly influenced pathways associated with spliceosomes, the cell cycle, Fanconi anemia, homologous recombination, ubiquitin-mediated proteolysis, nucleotide excision repair, oocyte meiosis, basal transcription factors, and endocytosis. Cyclin A2, Cyclin B1, Cyclin E2, CDK1, $C D K 6$, and $C D K 8$ were included among the cell cycle pathway genes affected by FR. BRCA1, BRCA2, and $P A L B 2$ were among the genes associated with the Fanconi anemia pathway. $B R C A 1$ and $B R C A 2$ were also included in the ubiquitin-mediated proteolysis and homologous recombination pathways, respectively.

\section{Effect of SF3B1 inhibition and SF3B1 mutations on driver genes}

Of 138 driver genes reported by Vogelstein [43], 52 oncogenes and 60 tumor suppressor genes were affected by FR treatment in either HCT116 or DLD1 cells (Tables 4, 5). Quantitative RT-PCR confirmed the inhibitory effect of FR treatment on 27 oncogenes including $B C L 2$, $C T N N B 1, E G F R, E R B B 2, K R A S$, and MET driver genes.

In FR-resistant clones, 36 genes were affected in either DLD/FR1 or HCT/FR1, of which the expression of two genes, RET and SETBP1, was increased in both clones by microarray (Table 6). In contrast to FR treatment, quantitative RT-PCR did not confirm the changes in gene expression in $\mathrm{HCT} / \mathrm{FR} 1$ and DLD/FR1 cells bearing SF3B1 gene mutations (Table 6).

\section{Effect of SF3B1 inhibition on Fanconi anemia- associated genes and cancer-associated genes}

qRT-PCR data confirmed that the expression of Fanconi anemia-associated genes including BRCA1, $B R C A 2, P A L B 2$, and $R A D 51$ and cancer-associated genes ( $A L D H 1 A 3$ and IGF1R) was strongly inhibited by FR treatment, as shown by microarray analysis (Table 3). Inhibition of $B R C A 1$ and $B R C A 2$ gene expression suggested a synergistic cytotoxic effect with PARP1 inhibitor based on previous findings in breast cancer with mutation of BRCA1 or BRCA2 [44]. PALB2, ALDH1A3, and $I G F 1 R$ were reported to show associations with sensitivity to mitomycin, stem cell markers, and cancer progression, respectively [45-47].

\section{Combination treatment with FR and olaparib}

Based on the above findings of inhibition of $B R C A 1$ and BRCA2 expression by FR, we assessed the effect of combination treatment with FR and olaparib. In DLD1 cells, pretreatment with FR enhanced cytotoxicity of olaparib $(0.5 \mu \mathrm{M}$ and $10 \mu \mathrm{M}: P<0.05)$ at a FR concentration of $2.5 \mathrm{ng} / \mathrm{ml}$ but not at $1 \mathrm{ng} / \mathrm{ml}$ (Figure 3C). In HCT116 cells, pretreatment with FR enhanced the cytotoxicity of olaparib $(0.1 \mu \mathrm{M}$ to $5 \mu \mathrm{M}: P<0.005)$ at $2.5 \mathrm{ng} / \mathrm{ml}$ but not at $1 \mathrm{ng} / \mathrm{ml}$. (Figure 3D). These findings are consistent with the data of combination index (CI). In DLD1 cells, CI was 0.84 and 1.08 at a FR concentration of $2.5 \mathrm{ng} / \mathrm{ml}$ and $1 \mathrm{ng} / \mathrm{ml}$, respectively. In HCT116 cells, CI was 0.93 and 1.37 at a FR concentration of $2.5 \mathrm{ng} / \mathrm{ml}$ and $1 \mathrm{ng} / \mathrm{ml}$, respectively. Synergistic effects were shown at a FR concentration of $2.5 \mathrm{ng} / \mathrm{m}$ in both DLD1 and HCT116.

\section{DISCUSSION}

In this study, we assessed the possible application of the splicing modulator FR for CRC treatment. FR showed effective cytotoxicity against CRC cells in vitro and in vivo. This is the first report to show the efficacy of FR analogues in solid tumors, although the antitumor effect was dependent on the cell line and was associated with severe toxicity in vivo. The instability of FR under serumcontaining conditions has been described $[5,9,11]$. FR analogues including SSA and Meayamycin appear to be more stable than FR in serum $[5,18]$; however, sufficient efficacy of FR analogues for solid tumors has not yet been demonstrated [18, 21, 22]. Although we considered that intraperitoneal administration of FR might reduce both toxicity and efficacy in vivo, FR via this route maintained both toxicity and efficacy. Therefore, improvement of 


\section{Table 3: Pathways with significant correlations in PC}

Rank

\section{Pathway}

$P$-value

Pathways with significant negative correlation in PC1

Spliceosome $\quad 0.0001$

Circadian rhythm 0.0027

$3 \quad$ p53 signaling pathway 0.0033

$\begin{array}{lll}4 & \text { mRNA surveillance pathway } & 0.0049\end{array}$

$5 \quad$ Neuroactive ligand-receptor interaction 0.0065

$6 \quad$ RNA transport

0.0079

$\begin{array}{llc}1 & \text { Cell cycle } & 0 \\ 2 & \text { Fanconi anemia pathway } & 0 \\ 3 & \text { Ubiquitin mediated proteolysis } & 0 \\ 4 & \text { Homologous recombination } & 0 \\ 5 & \text { Nucleotide excision repair } & 0 \\ 6 & \text { Oocyte meiosis } & 0 \\ 7 & \text { Basal transcription factors } & 0 \\ 8 & \text { Endocytosis } & 0 \\ 9 & \text { SNARE interactions in vesicular transport } & 0.0001 \\ 10 & \text { Progesterone-mediated oocyte maturation } & 0.0001 \\ 11 & \text { Amino sugar and nucleotide sugar metabolism } & 0.0003 \\ 12 & \text { Glycerophospholipid metabolism } & 0.0017 \\ 13 & \text { Viral carcinogenesis } & 0.0022 \\ 14 & \text { DNA replication } & 0.0031 \\ 15 & \text { Phosphatidylinositol signaling system } & 0.0040 \\ 16 & \text { Inositol phosphate metabolism } & 0.0042 \\ 17 & \text { Pancreatic cancer } & 0.0042 \\ 18 & \text { Adherens junction } & 0.0058 \\ 19 & \text { HTLV-I infection } & 0.0070 \\ 20 & \text { Fructose and mannose metabolism } & 0.0095\end{array}$

Pathways with significant positive correlation in PC2

$\begin{array}{llc}1 & \text { Metabolism of xenobiotics by cytochrome P450 } & 0 \\ 2 & \text { Chemical carcinogenesis } & 0.0001 \\ 3 & \text { Drug metabolism - cytochrome P450 } & 0.0001 \\ 4 & \text { Legionellosis } & 0.0010 \\ 5 & \text { Valine, leucine, and isoleucine degradation } & 0.0012 \\ 6 & \text { Pentose and glucuronate interconversions } & 0.0015 \\ 7 & \text { Glutathione metabolism } & 0.0028 \\ 8 & \text { Ascorbate and aldarate metabolism } & 0.0030 \\ 9 & \text { TGF-beta signaling pathway } & 0.0030 \\ 10 & \text { Pathogenic Escherichia coli infection } & 0.0044 \\ 11 & \text { Toxoplasmosis } & 0.0062 \\ 12 & \text { Pertussis } & 0.0071 \\ 13 & \text { Cytokine-cytokine receptor interaction } & 0.0076 \\ 14 & \text { Amoebiasis } & 0.0080\end{array}$


Pathways with significant negative correlation in PC2

$\begin{array}{llc}1 & \text { Type I diabetes mellitus } & 0 \\ 2 & \text { Allograft rejection } & 0.0001 \\ 3 & \text { Protein digestion and absorption } & 0.0001 \\ 4 & \text { Focal adhesion } & 0.0001 \\ 5 & \text { PI3K-Akt signaling pathway } & 0.0002 \\ 6 & \text { Asthma } & 0.0003 \\ 7 & \text { Viral myocarditis } & 0.0003 \\ 8 & \text { ECM-receptor interaction } & 0.0006 \\ 9 & \text { Graft-versus-host disease } & 0.0006 \\ 10 & \text { Cell adhesion molecules (CAMs) } & 0.0006 \\ 11 & \text { Axon guidance } & 0.0009 \\ 12 & \text { Autoimmune thyroid disease } & 0.0010 \\ 13 & \text { Nicotine addiction } & 0.0010 \\ 14 & \text { MAPK signaling pathway } & 0.0011 \\ 15 & \text { Arginine and proline metabolism } & 0.0012 \\ 16 & \text { Inflammatory bowel disease (IBD) } & 0.0018 \\ 17 & \text { Glutamatergic synapse } & 0.0020 \\ 18 & \text { Proteoglycans in cancer } & 0.0020 \\ 19 & \text { Endocytosis } & 0.0043 \\ 20 & \text { Calcium signaling pathway } & 0.0050 \\ 21 & \text { Staphylococcus aureus infection } & 0.0052 \\ 22 & \text { Intestinal immune network for IgA production } & 0.0060 \\ 23 & \text { Retrograde endocannabinoid signaling } & 0.0082\end{array}$

drug delivery to reduce toxicity is indispensable for monotherapy.

All of the FR-resistant clones carried mutations in codon 1074 of the $S F 3 B 1$ gene, which is consistent with a previous report on another SF3B1 inhibitor, Pladienolide $[16,23]$. In contrast, DLD1, COLO829, and HCC38 cells, which contained mutations at other sites in the $S F 3 B 1$ gene, were sensitive to FR. Therefore, mutation sites associated with FR sensitivity are different from those associated with cancer progression. Our study also showed low frequencies of $S F 3 B 1$ gene mutations and no mutations in codon 1074 of the SF3B1 gene in CRC patient samples. Thus, these results indicate that CRC cells, and possibly all cancer cells, are intrinsically sensitive to splicing modulators.

The influence of FR on alternative splicing of $M D M 2$ and CRNDE as a result of splicing modulation was abrogated in these FR-resistant clones. Moreover, the effect of FR on gene expression, including suppression of oncogenes and cancer-associated genes, was also abolished in FR-resistant clones. These results indicated that the cytotoxicity of FR was associated with its influence on gene splicing and gene expression through inhibition of SF3B1 function.
Splicing modulators have been reported to inhibit expression of VEGF, c-MYC, and MCL-1 [12, 22, 48]. A previous study reported downregulation of VEGF and MCL-1 and upregulation of c-MYC by a splicing modulator. In our microarray study, downregulation of VEGFA in HCT116 and upregulation of MYC in both DLD1 and HCT116 were the same as the previous study. However, MCL1 was upregulated in DLD1 and does not reflect the findings of the previous report. Differences from previous studies may depend on variations in cell types and evaluation methods.

Our study suggested that splicing modulation might downregulate many oncogenes and cancer-associated genes. Moreover, splicing modulators could influence gene expression associated with drug sensitivity. Inhibition of BRCA1 and BRCA2 expression by FR suggested a synergistic cytotoxic effect with olaparib based on the fact that this PARP1 inhibitor is effective in breast cancer with genetic deficiencies in BRCA1 or BRCA2 [44]. The enhanced cytotoxicity of olaparib after pretreatment with FR in this study supports this hypothesis. Combination therapy with splicing modulators to overcome drug resistance has been reported in lung cancer cells and melanoma [17, 21]. 
Table 4: Oncogenes and cancer-associated genes affected by SF3B1 inhibition by FR

\begin{tabular}{|c|c|c|c|c|c|c|c|c|c|}
\hline \multirow{3}{*}{$\begin{array}{c}\text { Gene } \\
\text { Symbol }\end{array}$} & \multicolumn{4}{|c|}{$\log _{2}$ ratio compared with no treatment } & \multirow{3}{*}{$\begin{array}{c}\text { Gene } \\
\text { Symbol }\end{array}$} & \multicolumn{4}{|c|}{$\log _{2}$ ratio compared with no treatment } \\
\hline & HCT116 & DLD1 & HCT116 & DLD1 & & HCT116 & DLD1 & HCT116 & DLD1 \\
\hline & \multicolumn{2}{|c|}{ Microarray } & \multicolumn{2}{|c|}{ qRT-PCR } & & \multicolumn{2}{|c|}{ Microarray } & \multicolumn{2}{|c|}{ qRT-PCR } \\
\hline & & ncogenes & & & $M A P 2 K 1$ & -0.34 & 1.25 & -6.57 & -5.57 \\
\hline$A B L 1$ & 2.92 & 1.99 & -0.82 & 0.46 & MCL1 & 0.36 & -0.19 & 1.68 & -0.02 \\
\hline$A K T 1$ & -0.49 & -1.22 & & & $M D M 2$ & 2.42 & -0.14 & -5.8 & -6.4 \\
\hline$A R$ & 1.40 & 3.21 & - & - & MDM4 & 1.47 & 1.60 & -1.15 & 0.96 \\
\hline$B C L 2$ & -1.33 & 2.04 & -5.85 & -1.55 & MED12 & -3.14 & -2.08 & -3.4 & -3.13 \\
\hline$B R A F$ & -0.82 & -1.58 & -3.17 & -0.69 & MET & -2.90 & -1.67 & -5.57 & -3.55 \\
\hline CARD11 & 1.67 & 1.18 & & & $M Y C$ & 1.58 & -1.48 & -0.28 & -3.39 \\
\hline$C B L$ & -4.47 & -1.76 & -4.54 & -3.09 & $c-M Y C$ & 2.54 & 0.00 & 2.33 & -0.8 \\
\hline CCND1 & 0.68 & -1.43 & - & - & MYCL1 & -3.50 & -3.47 & -5.7 & -6.23 \\
\hline$C R L F 2$ & 1.20 & 1.12 & - & - & $M Y C N$ & 1.61 & -2.19 & - & - \\
\hline CSF1R & 0.73 & 1.59 & - & - & MYD 88 & -2.00 & -2.14 & -6.72 & -4.86 \\
\hline CTNNB1 & -1.10 & -1.00 & -1.8 & -2.18 & NCOA3 & -3.95 & 0.32 & -4.99 & -3.94 \\
\hline DNMT1 & 3.05 & -2.11 & -2.6 & -4.29 & $N K X 2-1$ & -1.68 & -0.93 & - & - \\
\hline DNMT3A & -2.12 & -1.73 & -5.8 & -5.4 & $N R A S$ & 1.46 & 1.40 & -0.04 & -0.14 \\
\hline$E G F R$ & -0.53 & -1.04 & -5.31 & -4.54 & PDGFRA & 1.63 & 0.99 & - & - \\
\hline$E R B B 2$ & -2.54 & -1.07 & -3.47 & -2.07 & PIK3A & -2.04 & 0.84 & -3.5 & -0.66 \\
\hline EZH2 & -4.94 & -2.72 & -5.62 & -5.67 & PTPN11 & -2.49 & -0.7 & - & - \\
\hline$F G F R 2$ & -2.93 & -2.06 & -4.59 & -4.2 & $R E T$ & -1.13 & 1.87 & - & - \\
\hline$F G F R 3$ & -3.64 & -2.06 & -6.75 & -4.08 & SETBP1 & 0.98 & 1.98 & - & - \\
\hline GATA2 & -1.58 & -0.41 & -3.64 & -3.68 & $S K P 2$ & -3.99 & -4.29 & -4.55 & -5.84 \\
\hline GNA11 & -1.25 & -1.72 & -3.33 & -5.18 & $S M O$ & -2.83 & 1.33 & -4.56 & -1.58 \\
\hline$G N A Q$ & -4.40 & -0.35 & -5.23 & -3.29 & $S P O P$ & -0.25 & -1.11 & - & - \\
\hline HIST1H3B & -3.63 & -3.16 & -1.76 & -1.78 & $S R S F 2$ & 2.79 & 0.89 & 1.67 & 0.84 \\
\hline$H R A S$ & 1.33 & -0.69 & -1.18 & -1.95 & $U 2 A F 1$ & -0.75 & -1.58 & - & - \\
\hline$I D H 1$ & -3.11 & -1.22 & -2.66 & -2.16 & $V E G F-A$ & -2.75 & -0.13 & -0.26 & 0.01 \\
\hline$J A K 1$ & -2.29 & -1.48 & -2.68 & -2.48 & & Cancer & ated gen & & \\
\hline$J A K 2$ & -1.87 & -1.19 & -6.34 & -6.4 & $A L D H 1 A 3$ & -5.87 & -4.25 & -5.89 & -6.16 \\
\hline$J A K 3$ & -1.66 & -0.42 & -4.2 & -1.65 & $I G F 1 R$ & -2.19 & -0.09 & -5.36 & -5.7 \\
\hline Kit & 1.6 & -6.3 & & -3.3 & $P A L B 2$ & -3.56 & -2.74 & -4.06 & -3.69 \\
\hline$K R A S$ & -3.18 & -1.32 & -6.57 & -5.57 & RAD51 & -6.06 & -1.46 & -5.88 & -5.4 \\
\hline LMO1 & -3.36 & 1.02 & - & - & & & & & \\
\hline
\end{tabular}

Abbreviations: qRT-PCR; quantitative reverse transcriptase polymerase chain reaction. 
Table 5: Tumor suppressor genes affected by SF3B1 inhibition by FR

\begin{tabular}{|c|c|c|c|c|c|c|c|c|c|}
\hline \multirow{3}{*}{$\begin{array}{c}\text { Gene } \\
\text { Symbol }\end{array}$} & \multicolumn{4}{|c|}{$\log _{2}$ ratio compared with no treatment } & \multirow{3}{*}{$\begin{array}{c}\text { Gene } \\
\text { Symbol }\end{array}$} & \multicolumn{4}{|c|}{$\log _{2}$ ratio compared with no treatment } \\
\hline & HCT116 & DLD1 & HCT116 & DLD1 & & HCT116 & DLD1 & HCT116 & DLD1 \\
\hline & \multicolumn{2}{|c|}{ Microarray } & \multicolumn{2}{|c|}{ qRT-PCR } & & \multicolumn{2}{|c|}{ Microarray } & \multicolumn{2}{|c|}{ qRT-PCR } \\
\hline$A C V R 1 B$ & 1.35 & 2.07 & & & MLL2 & -3.16 & -1.97 & & \\
\hline$A P C$ & 0.48 & 1.22 & & & $M L L 3$ & -0.42 & -1.01 & & \\
\hline ARIDIA & 0.03 & 1.26 & & & MSH2 & -5.23 & -2.88 & & \\
\hline ARID2 & -1.38 & 0.55 & & & MSH6 & -3.82 & 1.47 & & \\
\hline ATM & -1.59 & -0.28 & -4.35 & -3.61 & $N F 1$ & -0.75 & -1.62 & & \\
\hline $\operatorname{ATRX}$ & -1.23 & 0.43 & & & $N F 2$ & -1.99 & -0.78 & & \\
\hline AXIN1 & -1.13 & -1.15 & & & NOTCH1 & -2.90 & -1.54 & -5.03 & -1.93 \\
\hline$B 2 M$ & 1.13 & 0.84 & & & NOTCH2 & -1.07 & -0.97 & & \\
\hline$B A P 1$ & 1.27 & 0.24 & & & PBRM1 & -1.32 & -1.63 & & \\
\hline$B C O R$ & 0.47 & 1.25 & & & PHF6 & -2.56 & -1.13 & & \\
\hline$B R C A 1$ & -6.10 & -3.87 & -4.88 & -5.15 & PIK3R1 & -2.68 & -0.73 & & \\
\hline$B R C A 2$ & -2.94 & -3.21 & -5.07 & -5.55 & PRDMI & 5.38 & 1.68 & & \\
\hline CASP8 & -2.04 & -0.81 & & & PTCH1 & 0.98 & 2.5 & & \\
\hline$C D C 73$ & 0.01 & -1.2 & & & PTEN & -1.95 & -0.81 & & \\
\hline$C D K N 2 A$ & 0.61 & 1.81 & & & $R B 1$ & -4.77 & -3.43 & -4.4 & -6.05 \\
\hline$C D K N 2 C$ & -4.96 & -1.9 & & & $R U N X 1$ & -1.25 & 0.41 & & \\
\hline CEBPA & -2.25 & -1.26 & & & SETD2 & 0.74 & 1.77 & & \\
\hline$C I C$ & 0.16 & -1.24 & & & $S M A D 2$ & -3.72 & -1.71 & & \\
\hline CREBBP & 0.79 & 1.98 & & & SMAD4 & -0.16 & 1.79 & & \\
\hline$C Y L D$ & -2.3 & -0.18 & & & SMARCA4 & -1.86 & -1.44 & & \\
\hline$D A X X$ & -1.89 & -0.54 & & & $S M A R C B 1$ & -3.33 & -0.71 & & \\
\hline$F A M 123 B$ & 1.84 & -0.01 & & & SOCS1 & -1.3 & 0.58 & & \\
\hline$F B X W 7$ & 4.19 & 1.35 & & & SOXO & 0.6 & -1.18 & & \\
\hline FUBP1 & -3.96 & -1.96 & & & STAG2 & -1.25 & -1.08 & & \\
\hline$H N F 1 A$ & 2.10 & 1.65 & & & STK11 & -0.78 & -1.12 & & \\
\hline KDM5C & 0.93 & 1.64 & & & TET2 & 2.89 & 2.99 & & \\
\hline$M A P 2 K 4$ & 2.12 & 0.31 & & & TNFAIP3 & 1.84 & 2.34 & & \\
\hline$M A P 3 K 1$ & -2.17 & -0.01 & & & TP53 & -1.08 & -0.4 & & \\
\hline MEN1 & -1.46 & -2.21 & & & $T S C 1$ & 2.66 & 3.64 & & \\
\hline$M L H 1$ & -3.30 & -2.00 & & & $W T 1$ & 1.58 & -1.62 & & \\
\hline
\end{tabular}

Our study showed low frequencies of $S F 3 B 1$ mutations and no mutations in codon 1074 of the $S F 3 B 1$ gene in CRC patient samples. These results indicate that CRC cells, and possibly all cancer cells, are intrinsically sensitive to splicing modulators.

$S F 3 B 1$ expression levels in the CRC patients of our study were not associated with tumor progression, in contrast to previous findings $[48,49]$. This discrepancy may reflect differences in sample conditions; we stored samples for RNA isolation in RNAlater at $-80^{\circ} \mathrm{C}$ whereas the other studies collected RNA from samples in which the RNA might be fragmented.

Our study has several limitations. First, the severe toxicity of FR in the xenograft model prevented us from further examining the efficacy of FR in vivo. However, the lower $\mathrm{IC}_{50}$ value of FR in RKO cells in vitro seemed to be associated with efficacy in vivo. Improved FR delivery in vivo is critical for sufficient efficacy and reduced toxicity. 
Table 6: Driver genes affected by $S F 3 B 1$ mutations

\begin{tabular}{|c|c|c|c|c|c|c|c|c|c|}
\hline \multirow{3}{*}{$\begin{array}{c}\text { Gene } \\
\text { symbol }\end{array}$} & \multicolumn{4}{|c|}{$\log _{2}$ ratio compared with parental cells } & \multirow{3}{*}{$\begin{array}{c}\text { Gene } \\
\text { symbol }\end{array}$} & \multicolumn{4}{|c|}{$\log _{2}$ ratio compared with parental cells } \\
\hline & $\begin{array}{c}\text { HCT/ } \\
\text { FR1 }\end{array}$ & $\begin{array}{l}\text { DLD/ } \\
\text { FR1 }\end{array}$ & $\begin{array}{c}\text { HCT/ } \\
\text { FR1 }\end{array}$ & $\begin{array}{c}\text { DLD/ } \\
\text { FR1 }\end{array}$ & & $\begin{array}{c}\text { HCT/ } \\
\text { FR1 }\end{array}$ & $\begin{array}{c}\text { DLD/ } \\
\text { FR1 }\end{array}$ & $\begin{array}{c}\text { HCT/ } \\
\text { FR1 }\end{array}$ & $\begin{array}{c}\text { DLD/ } \\
\text { FR1 }\end{array}$ \\
\hline & \multicolumn{2}{|c|}{ Microarray } & \multicolumn{2}{|c|}{ qRT-PCR } & & \multicolumn{2}{|c|}{ Microarray } & \multicolumn{2}{|c|}{ qRT-PCR } \\
\hline$A B L 1$ & -1.03 & 0.03 & & & NCOA3 & 1.08 & 0.911 & -0.04 & -0.04 \\
\hline$A R I D I B$ & -1.27 & -0.10 & & & NCOR1 & 1.03 & 0.00 & & \\
\hline$B 2 M$ & 1.17 & 0.09 & & & NOTCH1 & 0.00 & 1.16 & 0.55 & 0.03 \\
\hline$B C L 2$ & -1.31 & 0.41 & -0.26 & -0.12 & PDGFRA & -0.04 & 2.77 & & \\
\hline $\mathrm{CDH1}$ & 2.16 & 0.10 & & & PIK3R1 & 1.70 & -0.28 & & \\
\hline$C D K N 2 A$ & -1.08 & -0.12 & & & PRDM1 & 0.69 & 1.32 & & \\
\hline CSF1R & -0.36 & 1.66 & -2.07 & 3.43 & PTCHI & 1.32 & 0.02 & & \\
\hline DNMT3A & 1.22 & 0.25 & 1.34 & -0.84 & $R E T$ & 1.01 & 1.13 & 0.56 & ND \\
\hline$E R B B 2$ & 1.22 & 0.35 & 1.35 & 0.08 & RNF43 & -7.04 & -0.32 & & \\
\hline$F G F R 2$ & 1.37 & 0.17 & 1.7 & -0.49 & $R U N X 1$ & -3.10 & -0.26 & & \\
\hline FGFR3 & 1.06 & 0.17 & 0.75 & -1.34 & SETBP1 & 2.01 & 2.07 & & \\
\hline GATA2 & 2.02 & 0.46 & 1.97 & 0.28 & SKP2 & -1.02 & 0.02 & -0.02 & -0.45 \\
\hline$G N A S$ & -1.86 & 1.47 & 0.63 & -0.47 & $S M O$ & 0.08 & 1.08 & 0.61 & 0.10 \\
\hline HNF1A & 0.11 & 1.26 & & & SOCS1 & -1.05 & 0.61 & & \\
\hline$I D H 1$ & 1.25 & 0.00 & 1.56 & -0.25 & STAG2 & -0.20 & -1.37 & & \\
\hline KDM6A & 1.29 & 0.05 & & & TNFAIP3 & -1.28 & 0.17 & & \\
\hline KLF4 & 1.85 & -0.34 & & & TSC1 & 0.56 & 1.22 & & \\
\hline$M Y C$ & -1.56 & -0.06 & -1.02 & -0.33 & $W T 1$ & -0.03 & -2.15 & & \\
\hline
\end{tabular}

Second, we did not show that mutations in codon 1074 of $S F 3 B 1$ definitively induced FR resistance, although the presence of codon 1074 mutations in all the FRresistant clones, in pladienolide-resistant clones, and in clones derived from CT26 cells with MSS strongly implicates a role for mutations in codon 1074 of SF3B1 in FR resistance. Third, the influence of FR on driver oncogenes and cancer-associated genes was not evaluated in other types of cancer and with other splicing modulators. A consistent effect on driver oncogenes and cancer-associated genes, regardless of cancer type and splicing modulator, will promote further study of splicing modulators. Finally, the effect of combination therapy was not confirmed in vivo because of a shortage of FR.

In conclusion, our study indicates the possible application of splicing modulators in combination therapy for the treatment of cancers including CRC through their influence on gene expression associated with drug sensitivity.

\section{MATERIALS AND METHODS}

\section{Drugs and chemicals}

FR, a gift from Astellas Pharma Inc. (Tokyo, Japan), and olaparib (Funakoshi, Tokyo, Japan) were dissolved in DMSO at a concentration of $100 \mu \mathrm{g} / \mathrm{ml}$ and stored at $-20^{\circ} \mathrm{C}$. OHP (Yakult Inc., Tokyo, Japan) was stored at $4^{\circ} \mathrm{C}$. 5-FU (Sigma-Aldrich Japan, Tokyo, Japan) was dissolved in phosphate-buffered saline at a concentration of $10 \mathrm{mM}$ and stored at $4^{\circ} \mathrm{C}$. All drugs were diluted in culture medium immediately before use.

\section{Cell lines and cloning of drug-resistant cells}

The human melanoma cell line COLO829, human breast cancer cell line $\mathrm{HCC} 38$, and murine colon tumor cell line CT26 were purchased from ATCC (Manassas, VA, USA). Human CRC cell lines Caco2, DLD1, HCT116, LoVo, HT29, and RKO were gifts from Dr. Hirofumi Yamamoto (Osaka University Graduate School of Medicine, Japan). All human cell lines were authenticated by ATCC using DNA profiling. Cells were maintained in appropriate media as follows: DMEM (DLD1 and HCT116), RPMI (HT29, RKO, COLO829, CT26, and HCC38), and Hanks-F12K (LoVo) supplemented with $10 \%$ fetal bovine serum, 10,000 units penicillin, $10 \mathrm{mg} /$ $\mathrm{ml}$ streptomycin, and $25 \mu \mathrm{g} / \mathrm{ml}$ amphotericin B. Culture media and fetal bovine serum were obtained from Life Technologies Japan (Tokyo, Japan). All cells were grown at $37^{\circ} \mathrm{C}$ in a humidified incubator with $5 \% \mathrm{CO}_{2}$. To obtain 
FR-resistant cells, cells were cultured in the presence of high concentrations of FR (20 ng/ml for DLD1 and $10 \mathrm{ng} /$ $\mathrm{ml}$ for all other cell lines).

\section{Patients}

Specimens were collected from 318 patients who underwent surgery at our department. All protocols were approved by the ethics committee of Hyogo College of Medicine as RINHI-0120 and all patients provided written informed consent. The specimens consisted of 312 CRC samples (299 primary tumors and 13 metastatic tumors), two small bowel gastrointestinal stromal tumors (GISTs), and one case each of small intestinal adenocarcinoma, rectal carcinoid, retroperitoneal liposarcoma, and metastatic renal cancer in the colon. The specimens were obtained with adjacent normal tissues for comparison and stored at $-80^{\circ} \mathrm{C}$ before use. For RNA analysis, samples were stored with RNAlater (Qiagen, Venlo, Netherlands).

\section{Drug treatment in cell culture}

Cells were seeded in $200 \mu \mathrm{l}$ medium in 96-well flat-bottom plates at a density of $2 \times 10^{3}$ cells per well. The next day, the medium was removed and various concentrations of FR $(0.1-500 \mathrm{ng} / \mathrm{ml})$, OHP $(0.1-500$ $\mu \mathrm{M})$, and 5-FU $(0.1-500 \mu \mathrm{M})$ were added. To assess the time dependency, cells were incubated with FR for $1 \mathrm{~h}, 3$ h, $6 \mathrm{~h}, 12 \mathrm{~h}$, and $96 \mathrm{~h}$. To assess the effect of combination treatment with FR and olaparib, cells were treated with FR $(0,1 \mathrm{ng} / \mathrm{ml}, 2.5 \mathrm{ng} / \mathrm{ml})$ for $1 \mathrm{~h}$ followed by treatment with olaparib at various concentrations for $96 \mathrm{~h}$. After drug treatment, cells were counted using a cell counting kit (Dojindo Laboratories, Kumamoto, Japan) according to the manufacturer's instructions. Half maximal inhibitory concentration $\left(\mathrm{IC}_{50}\right)$ was calculated as the concentration that corresponded to a 50\% reduction in cellular proliferation compared with untreated cells. Experiments were independently performed at least three times and data are shown as means \pm standard deviations.

\section{Mutation analysis of SF3B1 by Sanger sequencing}

Genomic DNA was extracted from eight cancer cell lines (six CRC cell lines, COLO829, and HCC38), nine FR-resistant clones, and 253 patient-derived malignant tumors (including $246 \mathrm{CRC}$ patients) using the QIAamp DNA mini kit (Qiagen) (Table 2). We analyzed all 25 exons of $S F 3 B 1$ in all cancer cell lines and FR-resistant clones in addition to 81 tumors, including $75 \mathrm{CRC}$ patients, by Sanger sequencing as previously described [26]. Based on these findings, we further examined specific $S F 3 B 1$ exons in the remaining 172 tumors, including $171 \mathrm{CRCs}$ (Table 2).

\section{Microsatellite instability}

Genomic DNA from patients was used to evaluate their microsatellite instability (MSI) status. The mononucleotide microsatellite markers BAT-25, BAT26, NR21, NR22, and NR24 were used for evaluation as previously described [50].

\section{Human tumor xenografts}

Five-week-old female BALB/cAJcl-/nu/nu mice were purchased from Japan Clea Inc. (Tokyo, Japan). Mouse care and experiments were performed under specific pathogen-free conditions. All animal protocols were approved by the Institutional Animal Care and Use Committee of Hyogo College of Medicine and performed at the Institute of Experimental Animal Sciences of Hyogo College of Medicine.

A total of $5 \times 10^{6}$ HCT116 or RKO cells were subcutaneously injected into mice and the resultant tumors were allowed to grow larger than $5 \mathrm{~mm}$ in diameter. FR $(0.5 \mathrm{mg} / \mathrm{kg}$ or $0.75 \mathrm{mg} / \mathrm{kg})$ was injected intraperitoneally every fourth day into seven mice that received HCT116 cells and nine mice that received RKO cells for a total of six treatments. Tumor volume was calculated as $a \times b^{2}$, where $a$ represents the tumor length and $b$ represents its width.

\section{Microarray}

A total of $1 \times 10^{6}$ DLD1, HCT116, DLD/FR1, or HCT/FR1 cells were seeded into P10 tissue culture plates. After overnight culture, the cells were incubated for a further $24 \mathrm{~h}$ with or without $10 \mathrm{ng} / \mathrm{ml} \mathrm{FR}$ and RNA was extracted using the TRIzol RNA Purification kit (Invitrogen, Waltham, MA, USA). Gene expression profiles were analyzed using the Agilent SurePrint G3 Human GE 8x60K v2 Microarray kit (Agilent Technologies, Santa Clara, CA, USA) according to the manufacturers' instructions at Dragon Genomic Center (Mie, Japan). The data set is available at Gene Expression Ominibus under accession number GSE58241.

\section{Microarray data analysis}

Signal data were imported into GeneSpring (Agilent) for analysis. Among the 40,380 probes evaluated to be suitable, 22,125 were extracted as differentially expressed genes based on signal fold-changes of $\geq 4$ and signal differences of $\geq 100$. Hierarchical analysis and principal component (PC) analysis were performed to explore similarities and differences in gene expression following FR treatment and in the presence of $S F 3 B 1$ mutations. Based on the principal analysis, probes in the first and second principal component were used for further Kyoto Encyclopedia of Genes and Genomes (KEGG) pathway analysis. 


\section{PCR and quantitative real-time reverse transcription PCR (qRT-PCR)}

Total RNA was extracted from CRC cell lines and samples from 80 CRC patients using an RNeasy Mini kit (Qiagen). CRC samples stored with RNAlater were used for qRT-PCR. After generation of cDNA using Superscript III reverse transcriptase (Invitrogen), PCR was performed using specific oligonucleotides (Supplementary Table 1) to quantify gene expression and for RNA sequencing of $S F 3 B 1$. Primers for $S F 3 B 1$ sequencing have been reported previously [26].

To assess MDM2 RNA splicing, products were analyzed by agarose gel electrophoresis and ethidium bromide staining [14]. qRT-PCR was performed using the Power SYBR Green Master Mix and appropriate primer pairs (Life Technologies, Supplementary Table 1). Data were collected from wells in triplicate and each experiment was performed at least twice. ${ }^{\Delta \Delta} \mathrm{CT}$ was calculated by evaluating the difference in ${ }^{\triangle} \mathrm{CT}$ between the target gene and GAPDH as a control. The methods used to assess variants of $C R N D E$ were reported previously [42].

\section{Statistical analysis}

Tukey-Kramer test was used to evaluate the $\mathrm{IC}_{50}$ of FR in cell lines. Dunnett's test was used to evaluate timeand dose-dependency of FR with $12 \mathrm{~h}$ treatment as the control. Dunnett's test was also used to assess the $\mathrm{IC}_{50}$ of FR, OHP, and 5-FU in FR-resistant clones relative to the parental cells. The efficacy of combination treatment of FR and olaparib was assessed by Dunnett's test relative to treatment without FR. Student's $t$-test was used to evaluate tumor volume in xenograft models. $P$-values less than 0.05 were considered statistically significant. To evaluate the effect of combination therapy of FR and olaparib, combination index (CI) was calculated [51]. A CI of less than 1 was considered to be a synergistic effect.

\section{Abbreviations}

CLL, chronic lymphocytic leukemia; CRC, colorectal cancer; CRNDE, colorectal neoplasia differentially expressed; EGFR, epidermal growth factor receptor; 5-FU, 5-fluorouracil; FR, FR901464; GIST, gastrointestinal stromal tumors; HDACI, histone deacetylase inhibitor; KEGG, Kyoto Encyclopedia of Genes and Genomes; $\mathrm{IC}_{50}$, half maximal inhibitory concentration; MDS, myelodysplastic syndrome; MSI, microsatellite instability; MSS, microsatellite stability; OHP, oxaliplatin; PC, principal component; SF3B1, splicing factor 3B subunit 1; VEGF, vascular endothelial growth factor.

\section{Author contributions}

TY conceived the study; TY, SK, AY, TK, ST performed experiments; TY, SK, MI, NT analyzed and interpreted data; TY wrote the manuscript; all authors reviewed the manuscript.

\section{ACKNOWLEDGMENTS}

We thank Dr. Hidenori Nakajima for introducing FR901464 to us. We also thank the joint-use research facilities and animal facilities of Hyogo College of Medicine and Takara Bio for collecting data. We thank Mary Derry, PhD ELS, and H. Nikki March, PhD, from Edanz Group (https://www.edanzediting.com/ac) for editing a draft of this manuscript.

\section{CONFLICTS OF INTEREST}

The authors declare no conflicts of interest.

\section{FUNDING}

This work was supported by the Japanese Society for the Promotion of Science (JSPS) KAKENHI Grant Number 23591975, Ministry of Education, Culture, Sports, Science and Technology HAITEKU Grant Number S1291009, and Grant-in-Aid for Researchers, Hyogo College of Medicine 2013.

\section{REFERENCES}

1. Nakajima H, Sato B, Fujita T, Takase S, Terano H, Okuhara M. New antitumor substances, FR901463, FR901464 and FR901465. I. Taxonomy, fermentation, isolation, physicochemical properties and biological activities. The Journal of Antibiotics. 1996; 49:1196-1203.

2. Nakajima H, Hori Y, Terano H, Okuhara M, Manda T, Matsumoto S, Shimomura K. New antitumor substances, FR901463, FR901464 and FR901465. II. Activities against experimental tumors in mice and mechanism of action. The Journal of Antibiotics. 1996; 49:1204-1211.

3. Ueda M, Nakajima H, Hori Y, Fujita T, Nishimura M, Goto T, Okuhara M. FR901228, a novel antitumor bicyclic depsipeptide produced by Chromobacterium violacium No. 968. I. Taxonomy, fermentation, isolation, physicochemical and biological properties, and antitumor activity. The Journal of Antibiotics. 1994; 47:301-310.

4. Nakajima H, Kim YB, Terano H, Yoshida M, Horinouchi S. FR901228, a potent antitumor antibiotic, is a novel histone deacetylase inhibitor. Exp Cell Res. 1998; 241:126-133.

5. Kaida D, Motoyoshi H, Tashiro E, Nojima T, Hagiwara M, Ishigami K, Watanabe H, Kitahara T, Yoshida T, Nakajima H, Tani T, Horinouchi S, Yoshida M. Spliceostatin A targets SF3b and inhibits both splicing and nuclear retention of $p$ re-mRNA. Nat Chem Biol. 2007; 3:576-583.

6. Eckschlager T, Plch J, Stiborova M, Hrabeta J. Histone Deacetylase Inhibitors as Anticancer Drugs. Int J Mol Sci. 2017; 18:E1414. 
7. Yamano T, Ura K, Morishita R, Nakajima H, Monden M, Kaneda Y. Amplification of transgene expression in vitro and in vivo using a novel inhibitor of histone deacetylase. Mol Ther. 2000; 1:574-580.

8. Kotake Y, Sagane K, Owa T, Mimori-Kiyosue Y, Shimizu H, Uesugi M, Ishihama Y, Iwata M, Mizui Y. Splicing factor SF3b as a target of the antitumor natural product pladienolide. Nat Chem Biol. 2007; 3:570-575.

9. Albert BJ, Sivaramakrishnan A, Naka T, Czaicki NL, Koide K. Total syntheses, fragmentation studies, and antitumor/ antiproliferative activities of FR901464 and its low picomolar analogue. J Am Chem Soc. 2007; 129:2648-59.

10. Lagisetti C, Pourpak A, Jiang Q, Cui X, Goronga T, Morris SW, Webb TR. Antitumor compounds based on a natural product consensus pharmacophore. J Med Chem. 2008; 51:6220-4.

11. Albert BJ, McPherson PA, O'Brien K, Czaicki NL, Destefino V, Osman S, Li M, Day BW, Grabowski PJ, Moore MJ, Vogt A, Koide K. Meayamycin inhibits premessenger RNA splicing and exhibits picomolar activity against multidrug-resistant cells. Mol Cancer Ther. 2009; 8:2308-18.

12. Furumai R, Uchida K, Komi Y, Yoneyama M, Ishigami K, Watanabe H, Kojima S, Yoshida M. Spliceostatin A blocks angiogenesis by inhibiting global gene expression including VEGF. Cancer Sci. 2010; 101:2483-2489.

13. Osman S, Waud W, Gorman G, Day B, Koide K. Evaluation of FR901464 analogues in vitro and in vivo. MedChemComm. 2011; 2:38-43.

14. Fan L, Lagisetti C, Edwards CC, Webb TR, Potter PM. Sudemycins, novel small molecule analogues of FR901464, induce alternative gene splicing. ACS Chem Biol. 2011; 6:582-589.

15. Osman S, Albert BJ, Wang Y, Li M, Czaicki NL, Koide K. Structural requirements for the antiproliferative activity of pre-mRNA splicing inhibitor FR901464. Chemistry. 2011; 17:895-904.

16. Yokoi A, Kotake Y, Takahashi K, Kadowaki T, Matsumoto Y, Minoshima Y, Sugi NH, Sagane K, Hamaguchi M, Iwata M, Mizui Y. Biological validation that SF3b is a target of the antitumor macrolide pladienolide. FEBS J. 2011; 278:4870-4880.

17. Gao Y, Koide K. Chemical perturbation of Mcl-1 premRNA splicing to induce apoptosis in cancer cells. ACS Chem Biol. 2013; 8:895-900.

18. Gao Y, Vogt A, Forsyth CJ, Koide K. Comparison of splicing factor $3 \mathrm{~b}$ inhibitors in human cells. Chembiochem. 2013; 14:49-52.

19. Lagisetti C, Palacios G, Goronga T, Freeman B, Caufield W, Webb TR. Optimization of antitumor modulators of premRNA splicing. J Med Chem. 2013; 56:10033-44.

20. Gao Y, Trivedi S, Ferris RL, Koide K. Regulation of HPV16 E6 and MCL1 by SF3B1 inhibitor in head and neck cancer cells. Sci Rep. 2014; 4:6098.
21. Salton M, Kasprzak WK, Voss T, Shapiro BA, Poulikakos PI, Misteli T. Inhibition of vemurafenib-resistant melanoma by interference with pre-mRNA splicing. Nat Commun. 2015; 6:7103.

22. Larrayoz M, Blakemore SJ, Dobson RC, Blunt MD, Rose-Zerilli MJ, Walewska R, Duncombe A, Oscier D, Koide K, Forconi F, Packham G, Yoshida M, Cragg MS, et al. The SF3B1 inhibitor spliceostatin A (SSA) elicits apoptosis in chronic lymphocytic leukaemia cells through downregulation of Mcl-1. Leukemia. 2016; 30:351-360.

23. Teng T, Tsai JH, Puyang X, Seiler M, Peng S, Prajapati S, Aird D, Buonamici S, Caleb B, Chan B, Corson L, Feala J, Fekkes $\mathrm{P}$, et al. Splicing modulators act at the branch point adenosine binding pocket defined by the PHF5A-SF3b complex. Nat Commun. 2017; 8:15522.

24. Carvalho T, Martins S, Rino J, Marinho S, CarmoFonseca M. Pharmacological inhibition of the spliceosome subunit SF3b triggers exon junction complex-independent nonsense-mediated decay. J Cell Sci. 2017; 130:1519-1531.

25. Yoshida K, Sanada M, Shiraishi Y, Nowak D, Nagata Y, Yamamoto R, Sato Y, Sato-Otsubo A, Kon A, Nagasaki M, Chalkidis G, Suzuki Y, Shiosaka M, et al. Frequent pathway mutations of splicing machinery in myelodysplasia. Nature. 2011; 478:64-69.

26. Papaemmanuil E, Cazzola M, Boultwood J, Malcovati L, Vyas P, Bowen D, Pellagatti A, Wainscoat JS, HellstromLindberg E, Gambacorti-Passerini C, Godfrey AL, Rapado I, Cvejic A, et al; Chronic Myeloid Disorders Working Group of the International Cancer Genome Consortium. Somatic SF3B1 mutation in myelodysplasia with ring sideroblasts. N Engl J Med. 2011; 365:1384-1395.

27. Malcovati L, Papaemmanuil E, Bowen DT, Boultwood J, Della Porta MG, Pascutto C, Travaglino E, Groves MJ, Godfrey AL, Ambaglio I, Gallì A, Da Vià MC, Conte S, et al; Chronic Myeloid Disorders Working Group of the International Cancer Genome Consortium and of the Associazione Italiana per la Ricerca sul Cancro Gruppo Italiano Malattie Mieloproliferative. Clinical significance of SF3B1 mutations in myelodysplastic syndromes and myelodysplastic/myeloproliferative neoplasms. Blood. 2011; 118:6239-6246.

28. Quesada V, Conde L, Villamor N, Ordóñez GR, Jares P, Bassaganyas L, Ramsay AJ, Beà S, Pinyol M, MartínezTrillos A, López-Guerra M, Colomer D, Navarro A, et al. Exome sequencing identifies recurrent mutations of the splicing factor SF3B1 gene in chronic lymphocytic leukemia. Nat Genet. 2011; 44:47-52.

29. Wang L, Lawrence MS, Wan Y, Stojanov P, Sougnez C, Stevenson K, Werner L, Sivachenko A, DeLuca DS, Zhang L, Zhang W, Vartanov AR, Fernandes SM, et al. SF3B1 and other novel cancer genes in chronic lymphocytic leukemia. N Engl J Med. 2011; 365:2497-2506.

30. Rossi D, Bruscaggin A, Spina V, Rasi S, Khiabanian H, Messina M, Fangazio M, Vaisitti T, Monti S, Chiaretti S, Guarini A, Del Giudice I, Cerri M, et al. Mutations of the 
SF3B1 splicing factor in chronic lymphocytic leukemia: association with progression and fludarabine-refractoriness. Blood. 2011; 118:6904-6908.

31. Harbour JW, Roberson ED, Anbunathan H, Onken MD, Worley LA, Bowcock AM. Recurrent mutations at codon 625 of the splicing factor SF3B1 in uveal melanoma. Nat Genet. 2013; 45:133-135.

32. Martin M, Maßhöfer L, Temming P, Rahmann S, Metz C, Bornfeld N, van de Nes J, Klein-Hitpass L, Hinnebusch AG, Horsthemke B, Lohmann DR, Zeschnigk M. Exome sequencing identifies recurrent somatic mutations in EIF1AX and SF3B1 in uveal melanoma with disomy 3. Nat Genet. 2013; 45:933-936.

33. Furney SJ, Pedersen M, Gentien D, Dumont AG, Rapinat A, Desjardins L, Turajlic S, Piperno-Neumann S, de la Grange P, Roman-Roman S, Stern MH, Marais R. SF3B1 mutations are associated with alternative splicing in uveal melanoma. Cancer Discov. 2013; 3:1122-1129.

34. Ellis MJ, Ding L, Shen D, Luo J, Suman VJ, Wallis JW, Van Tine BA, Hoog J, Goiffon RJ, Goldstein TC, Ng S, Lin L, Crowder R, et al. Whole-genome analysis informs breast cancer response to aromatase inhibition. Nature. 2012; 486:353-360.

35. Maguire SL, Leonidou A, Wai $\mathrm{P}$, Marchiò $\mathrm{C}, \mathrm{Ng} \mathrm{CK}$, Sapino A, Salomon AV, Reis-Filho JS, Weigelt B, Natrajan RC. SF3B1 mutations constitute a novel therapeutic target in breast cancer. J Pathol. 2015; 235:571-580.

36. Biankin AV, Waddell N, Kassahn KS, Gingras MC, Muthuswamy LB, Johns AL, Miller DK, Wilson PJ, Patch AM, Wu J, Chang DK, Cowley MJ, Gardiner BB, et al. Pancreatic cancer genomes reveal aberrations in axon guidance pathway genes. Nature. 2012; 491:399-405.

37. Ferlay J, Soerjomataram I, Dikshit R, Eser S, Mathers C, Rebelo M, Parkin DM, Forman D, Bray F. Cancer incidence and mortality worldwide: sources, methods and major patterns in GLOBOCAN 2012. Int J Cancer. 2015; 136:E359-E386.

38. Benson AB, Venook AP, Cederquist L, Chan E, Chen YJ, Cooper HS, Deming D, Engstrom PF, Enzinger PC, Fichera A, Grem JL, Grothey A, Hochster HS, et al. Colon Cancer, Version 1.2017, NCCN Clinical Practice Guidelines in Oncology. J Natl Compr Canc Netw. 2017; 15:370-398.

39. Branch P, Hampson R, Karran P. DNA mismatch binding defects, DNA damage tolerance, and mutator phenotypes in human colorectal carcinoma cell lines. Cancer Res. 1995; 55:2304-2309.

40. Castle JC, Loewer M, Boegel S, de Graaf J, Bender C, Tadmor AD, Boisguerin V, Bukur T, Sorn P, Paret C, Diken M, Kreiter S, Türeci Ö, Sahin U. Immunomic, genomic and transcriptomic characterization of CT26 colorectal carcinoma. BMC Genomics. 2014; 15:190.

41. Sobin LH, Gospodarowicz MK, Wittekind C. TNM classification of malignant tumours. 7th ed. WileyBlackwell: New York, USA. 2009.
42. Graham LD, Pedersen SK, Brown GS, Ho T, Kassir Z, Moynihan AT, Vizgoft EK, Dunne R, Pimlott L, Young GP, Lapointe LC, Molloy PL. Colorectal Neoplasia Differentially Expressed (CRNDE), a Novel Gene with Elevated Expression in Colorectal Adenomas and Adenocarcinomas. Genes Cancer. 2011; 8:829-840. https://doi.org/10.1177/1947601911431081.

43. Vogelstein B, Papadopoulos N, Velculescu VE, Zhou S, Diaz LA Jr, Kinzler KW. Cancer genome landscapes. Science. 2013; 339:1546-1558.

44. Farmer H, McCabe N, Lord CJ, Tutt AN, Johnson DA, Richardson TB, Santarosa M, Dillon KJ, Hickson I, Knights C, Martin NM, Jackson SP, Smith GC, et al. Targeting the DNA repair defect in BRCA mutant cells as a therapeutic strategy. Nature. 2005; 434:917-921.

45. Villarroel MC, Rajeshkumar NV, Garrido-Laguna I, De Jesus-Acosta A, Jones S, Maitra A, Hruban RH, Eshleman JR, Klein A, Laheru D, Donehower R, Hidalgo M. Personalizing cancer treatment in the age of global genomic analyses: PALB2 gene mutations and the response to DNA damaging agents in pancreatic cancer. Mol Cancer Ther. 2011; 10:3-8.

46. Duan JJ, Cai J, Guo YF, Bian XW, Yu SC. ALDH1A3, a metabolic target for cancer diagnosis and therapy. Int $\mathrm{J}$ Cancer. 2016; 139:965-975.

47. Qu X, Wu Z, Dong W, Zhang T, Wang L, Pang Z, Ma W, Du J. Update of IGF-1 receptor inhibitor (ganitumab, dalotuzumab, cixutumumab, teprotumumab and figitumumab) effects on cancer therapy. Oncotarget. 2017; 8:29501-29518. https://doi.org/10.18632/oncotarget.15704.

48. Matsushita K, Kajiwara T, Tamura M, Satoh M, Tanaka N, Tomonaga T, Matsubara H, Shimada H, Yoshimoto R, Ito A, Kubo S, Natsume T, Levens D, et al. SAP155-mediated splicing of FUSE-binding protein-interacting repressor serves as a molecular switch for c-myc gene expression. Mol Cancer Res. 2012; 10:787-799.

49. Gökmen-Polar Y, Neelamraju Y, Goswami CP, Gu X, Nallamothu G, Janga SC, Badve S. Expression levels of SF3B3 correlate with prognosis and endocrine resistance in estrogen receptor-positive breast cancer. Mod Pathol. 2015; 28:677-685.

50. Suraweera N, Duval A, Reperant M, Vaury C, Furlan D, Leroy K, Seruca R, Iacopetta B, Hamelin R. Evaluation of tumor microsatellite instability using five quasimonomorphic mononucleotide repeats and pentaplex PCR. Gastroenterology. 2002; 123:1804-1811.

51. Foucquier J, Guedj M. Analysis of drug combinations: current methodological landscape. Pharmacol Res Perspect. 2015; 3:e00149. 